\title{
Cultivation of Students' Thinking Ability in the Teaching of Business English Reading
}

\author{
Enhua Zhang, ${ }^{1, *}$ \\ ${ }^{1}$ School of Foreign Languages, Anshan Normal University, Anshan, China \\ *Corresponding author. Email: 470235323@qq.com
}

\begin{abstract}
This article aims to explore ways to improve college students' thinking ability in the daily classroom teaching of business English reading. It first discusses the need to cultivate students' thinking ability, then analyzes some causes of the lack of thinking ability of college students, and finally focuses on possible ways of the cultivation of students' thinking ability, such as the use of idea changing, heuristic teaching, group learning, Jigsaw learning and diversified assessment. However, how to effectively improve students' thinking ability in daily teaching still remains a difficult problem.
\end{abstract}

Keywords: Thinking Ability, Business English, Reading, Cultivation

\section{INTRODUCTION}

More and more colleges and universities, since the $21 \mathrm{st}$ century, have regarded the cultivation of students' thinking ability as one of the goals of higher education. The concept of thinking ability can be traced back to Dewey's Reflective Thinking, which, put forward by the American educator John Dewey in 1933, refers to the repeated, serious, and continuous deep thinking about a certain problem [1]. Nowadays, thinking ability is regarded as the thinking process by which individuals can analyze their behaviors or the behaviors of others, and then draw their own conclusions. In the case of classroom teaching, students can use the knowledge they have mastered to synthesize and evaluate existing materials, conduct objective and rational analysis of others' views and behaviors, and be able to make exploratory answers to challenging questions. [14]

In 1998, Huang Yuanshen pointed out foreign language majors' lack of thinking ability, which is mainly reflected in the poor logical thinking ability, lack of analysis, synthesis, judgment, reasoning, thinking and discriminative ability. [6] This marks the prelude to the study of thinking ability and its cultivation for foreign language majors. He Qixin [5] also claimed in "Several Opinions on the Reform of Undergraduate Education for Foreign Languages Majors" that in the process of language skills training, emphasis is placed on imitation and memorization, while students' thinking ability, innovation ability, the ability to analyze problems and provide independent opinions are ignored. WTO and Foreign Languages Professional Education also asserted that foreign language graduates show worrying lack of thinking ability and intelligence deficiency.

Statistics show that since 2008, the cultivation of English majors' thinking ability has attracted the attention of domestic English academic circles, and the research and application of thinking ability is gradually entering an active period. [11] The research on the thinking ability of English majors mainly involves the following six aspects: reasons for the lack of thinking ability, the solution to the lack of thinking ability, the empirical research on the lack of thinking ability, the research on the cultivation of thinking ability and the curriculum setting of English majors, the cultivation of thinking ability, the study of teaching methods and the teaching methods of specific professional courses, and the study of measuring tools of thinking ability. This article aims to explore the necessity of thinking ability, reasons for the lack of thinking ability, and how to cultivate thinking ability in the course of Business English Reading teaching. [11]

\section{NECESSITY OF CULTIVATING THINKING ABILITY}

In addition to inheriting cultural knowledge, colleges and universities also have a strong critical function. This does not mean that they, as the critical center of society, negatively expose or even slander the society. Rather, they point out deficiencies in government decision-making through critical thinking, attract public attention, implement supervision, and make improvements. Higher education should be independent of the market mechanism. Besides serving the society, it should also form a strong social criticism force. However, in schools, if we only tend to teach students how to read, imitate and memorize and ignore the cultivation of their ability to think critically, they will suffer from the lack of thinking ability, which eventually will lead to the dysfunction of colleges and universities as a critical centre of the society. [9]

Richard Levin, former president of Yale University, when talking about general education advocated by the school, emphasized that no matter what the content of the course is, no matter how it develops, I want to say that the purpose of general education is not to teach people what to think about, but how to think. [2] In other words, one of the main goals of higher education is to achieve what 
people often call "freedom education", teaching students the correct way of thinking, broad-mindedness, neither inferiority nor arrogance, and humble and cautious views of themselves and others, at the same time maintaining a curious and questioning attitude. Therefore, besides their language use, colleges and universities should also pay attention to the cultivation of students' ability to meet social needs, adapt to social development, and solve various practical problems.

In addition, compared with ordinary reading articles, business English reading materials have wider coverage and a stronger sense of the times. The diversification of content will inevitably lead to ideological diversification. The authors' times, life experiences, education backgrounds, knowledge structures, and the purposes of the articles always have their limitations, and they are likely to have one-sided views, or even prejudices. The authors are not necessarily smarter than their readers. Students should dare to question, reflect, and challenge. This shows that the cultivation of students' thinking ability in business English reading teaching is particularly important.

\section{REASONS FOR THE LACK OF THINKING ABILITY}

\subsection{Language-oriented SLA}

Over the years, the direction of English teaching has been to consolidate students' basic language skills and cultivate qualified English talents. Due to the language-oriented SLA, the cultivation of talents' quality has been neglected to some extent. English classroom teaching focuses on the practice of second language acquisition and language skills. The teaching methods are mainly reciting, memorizing, imitation, interpretation, etc. There is a serious lack of teaching activities that are conducive to the divergence of students' thinking, such as classroom discussions and work reviews. The ability of students to think independently and judge rationally has not been cultivated. Even in order to complete teaching tasks and improve the pass rate of language proficiency tests, the teacher sometimes has to do cramming teaching. In addition, the standardization of examinations, the excessive proportion of objective questions, and the tendency of the answers to subjective questions to be standardized have restricted the cultivation of students' thinking ability to a certain extent.

\subsection{Teacher-centred Classroom Teaching}

For a long time, English teaching tends to be teacher-centered. Students are accustomed to passively listening to lectures, understanding them, memorizing them and accepting them all. They are unwilling to actively think or give up opportunities for analysis and thinking. Students' classroom behaviors are limited to passive listening, reading, writing, and translation, and their thinking is constrained by limited textbook texts. There is a lack of adequate discourse, information and emotional communication between the teacher and students and between students and students. Over time, due to the lack of motivation from positive emotional factors, students' curiosity, self-confidence, and questioning ability will gradually diminish or even disappear, and the learning efficiency of English language skills will also be greatly reduced.

\subsection{Exam-centred Curriculum}

Thinking ability is acquired through nurture and training. At present, the teaching methods of thinking ability are divided into two types: independent curriculum and content-based. The former has a special curriculum system for students to study, and the latter relies on foreign language learning as a medium and tool to improve language skills and thinking ability. At present, the training of students' thinking ability in English teaching is mainly the latter, which is to strengthen the training of students' thinking ability through the subtle effect of English teaching, so that the development of students' language skills and thinking skills can promote each other. However, the domestic English curriculum generally has the problem of emphasizing input and neglecting output, and more emphasis is placed on receptive skills training. Most of the curriculum content is set up around examinations. Students' abilities are often measured by examination results. Therefore, students have a single knowledge structure. With a narrow field of view, it is difficult to motivate students and help motivate them to think through learning a second language, learn new knowledge, and cultivate their thinking ability. [12]

\subsection{Students' Lack of Independent and Personalized Learning}

Cognitive skills such as analysis, reasoning, and evaluation are important forms of thinking ability, and one of the effective ways to cultivate them is independent learning and personalized learning. Littlewood [4] clearly pointed out that the essence of independent learning is an ability to judge, think and act independently with transcendental and critical characteristics. However, students are often in a position of passively receiving knowledge installation in English teaching. The learning progress, learning methods and skills, and even learning effects are all handled by the teacher. As a result, students lack the mastery of learning methods, seldom learn English knowledge other than classroom teaching or textbook texts, and cannot make full use of existing knowledge, life experience and values to make independent and rational analysis and judgments. [10] 


\section{WAYS TO IMPROVE STUDENTS' THINKING ABILITY}

In addition to helping students consolidate their language skills and increase business knowledge, business English reading also emphasizes the cultivation of thinking ability such as independent thinking and critical thinking. "National Standards for the Quality of Undergraduate Teaching for Business English Majors in Colleges and Universities" (for trial implementation) clearly stipulates that the business English major aims to cultivate compound and applied English talents who have the ability to use English, the ability of cross-cultural communication, thinking ability, business practice innovation and independent learning, and can engage in international business work. It can be seen that the cultivation of students' thinking ability should be one of the teaching goals of all courses of Business English. [14]

To cultivate students' thinking ability, the teacher can organize business English classroom teaching through the following ways.

\subsection{Change Ideas and Encourage Students to Question}

Since ancient times, the teacher has always been the main source for students to acquire knowledge. However, with the rapid development of science and technology, this traditional teacher-centered teaching model has severely hindered the development of students' thinking ability. Therefore, we must change our ideas and transform to student-centered teaching. The teacher should guide and act as an intermediary in the teaching process. The teacher should stimulate students' interest and passion for independent learning so as to actively acquire knowledge instead of passively accepting it. In this process, the teacher should encourage students to identify, analyze and select materials, so that students can think actively, love thinking, and improve their critical thinking skills. [13] To effectively cultivate students' thinking ability, the teacher needs to actively change his ideas. The teacher needs to understand that students' questioning is not contempt or challenge to him. The teacher should actively create an equal classroom environment, encourage students to question and actively communicate with them.

\subsection{Adopt Heuristic Teaching}

Heuristic teaching regards students as the center of classroom teaching, in which the teacher and students experience, create, and develop together in interactive situations. In this process, the teacher leads, organizes, guides and promotes students' learning, research, and exploration. The teacher doesn't design some content-related questions according to the textbook, and then asks students to answer them. Instead, the teacher guides students to think, to ask questions, to find problems, to analyze them and solve them. Under the guidance of the teacher, students find problems around certain teaching content, propose hypotheses, collect facts and information, use their background knowledge to identify, reason, and demonstrate the information obtained, and finally verify the hypotheses. In this process, students are the main body of learning, and the teacher only helps students to make self-judgment and self-correction. It can be seen that heuristic teaching helps to cultivate students' successful thinking ability and is an effective and important way to cultivate students' critical thinking. As far as business English reading is concerned, it covers a wide range of content, which is more suitable for the adoption of heuristic teaching. [7]

\subsection{Establish a Group Learning Mechanism}

The teacher divides his class into several heterogeneous study groups according to the differences in academic level, ability orientation, personality characteristics and gender of the whole class. There are generally four to six people in each group. Each member is assigned a frequently-rotated role. Then the teacher assigns the same designed learning content to each group. The content should be challenging, neither too difficult nor too simple, and cannot be beyond students' existing knowledge structure and their current cognitive abilities. The process of group learning is a process in which group members exchange their ideas, learn from each other, and make progress together, and then display the results within the specified time. As an organizer, guide and facilitator of group learning, the teacher, in the process of organizing group learning, should try to maximize students' participation and formulate reasonable rules to ensure that each member of the group can actively participate in group learning. When group members are presenting their results, the teacher should listen carefully to their presentation and give timely evaluations, affirm their achievements, and point out their problems and the direction of their efforts. This can not only reflect the status of students as the main body of learning, but can promote the communication and exchange of knowledge, ideas and thinking between the teacher and students and between students and students, which is conducive to the improvement of students thinking ability.

\subsection{Implement Jigsaw Learning}

Jigsaw learning is developed based on Slavin's [3] Jigsaw learning II, which is a learning activity in the form of partner teaching. This learning method has completely subverted the traditional teaching model. According to this teaching method, the teacher divides the learning materials into several parts, appoints each student group to choose one of them, group members read together, cooperate in preparing lessons, and design corresponding test questions 
according to their own group teaching content, and then interact with other groups.

After the mutual teaching and learning between groups, the teacher combines the test questions designed by each group into a test paper to evaluate how well students have learned. Each group must review the test questions they have designed, summarize the answers and give feedback to the class. In this way, classroom teaching has changed from "The teacher teaches and students listen." to cooperative learning among group members and between groups. Each group member has the dual identity of being both a teacher and a student. As the organizer of the classroom teaching, the teacher needs to comment on the performance of each group, instruct students to sort out, summarize, synthesize and compare scattered knowledge points after mutual teaching and learning between groups. In this teaching process, the ability of students to learn independently has been improved. It is the most effective way to cultivate students' thinking ability.

\subsection{Adopt diversified assessment}

Currently, many colleges and universities are in the reform process of transitioning from final assessment to process assessment. In addition to the final exam results, students' attendance, class participation, completion of off-class homework, and usual quizzes are all included in the assessment. Business English reading, as a linguistic liberal arts course, should pay more attention to diversification, emphasis on process and ability. It should adopt diversified forms of assessment, increase the proportion of process assessment in the total assessment results, strengthen the management of students' learning process, and further emphasize the status of students as the main body of learning.

The final exam should be more contemporary and practical, appropriately reduce the proportion of objective questions, and strengthen the evaluation of language skills". [8] Class discussions, book reports, etc. should also account for a certain proportion of the final assessment results, because a lot of reading is an indispensable part of language teaching. Students need a lot of extracurricular reading to prepare oral reports, book reports, etc., and then conduct a summary analysis of the materials they have read, select appropriate materials for oral reports, or select unique perspectives to write reports. Through this process, students can improve their ability to distinguish the authenticity, the ability of inductive analysis and the ability to reason and prove, which is precisely the core of thinking ability.

\section{CONCLUSION}

At present, a consensus has been reached on the improvement of the thinking ability of foreign language students, which is very necessary and realistic. This article aims to discuss ways to improve students' thinking ability by analyzing some of the causes of students' lack of thinking ability and then summarizing several teaching strategies used in business English reading classes. However, how to effectively improve students' thinking ability in daily teaching still remains a difficult problem.

\section{REFERENCES}

[1] J. Dewey, "How We Think", A Restatement of the Relation of Reflective Thinking to the Educative Process. M. Boston D. C. Health \& Company, 1993.

[2] R. Levin, "University Work”, Foreign Language Press, 2004

[3] R. E. Slavin, "An introduction to cooperative learning”, New York: Longman, 1983.

[4] W. Littlewood, "Communicative Language Teaching”, Cambridge University Press, 1991.

[5] Q.X. He, "Several opinions on the reform of foreign language undergraduate education", Foreign Language Teaching and Research, 1999.

[6] Y.S. Huang, "Absence of Thinking Ability", Foreign Languages and Foreign Language Teaching, 1998.

[7] X.H. Liu, "A Brief Analysis of the Construction of the Cultivation Mode of Thinking Ability in College English”, Teaching. Campus English, 2019.

[8] Y.X. Li, "The Enlightenment of Canadian College English Teaching Skills and Methods to my country", Innovation and Entrepreneurship Education, 2011.

[9] L.Y. Ma, "On the Cultivation of Critical Thinking Ability of English Majors", Journal of Changzhi University, 2014.

[10] Y. Meng, "Analysis of the Causes of Students' Lack of Thinking Ability in College English Teaching" Yangtze River Series Theoretical Research, 2016.

[11] H.H. Xia, "Research on Influencing Factors and Cultivation Strategies of Critical Thinking of College Students", Educational Research, 2017.

[12] S.X. Yang, "College English Classroom Activities and Cultivation of Thinking Ability", High Education Journal, 2016.

[13] Z.Y. Zheng, "Research on the Cultivation Mode of Thinking Ability in College English Teaching" Journal of Jiangxi Vocational and Technical College of Electric Power, 2019.

[14] Y.L. Zhao, "Business English reading teaching and the cultivation of students' critical thinking ability", College English Teaching and Research, 2017. 